\title{
Determinants of Teachers' Use of Instructional Resource in Teaching Pre- Primary School Science and Mathematics Activities In Machakos County, Kenya
}

\author{
Jackson Ombasa Ayiema ${ }^{1}$, Teresa Mwoma ${ }^{2}$, Hudson Ouko ${ }^{2}$ \\ ${ }^{1}$ Department of early childhood studies and special needs ecation Kenyatta university Kenya, \\ jacksonayiema@gmail.com \\ ${ }^{2}$ Kenyatta University, Kenya
}

\section{ABSTRACT}

The continuous poor results of science and mathematics in Athi-River Sub-County of Machakos County-Kenya has yielded to the study of determinants of pre-primary school teachers' use of instructional resources in teaching science and mathematics activities. The effects of use of the instructional resources in learning achievement which has led to poor performance in science and mathematics activities in the current study locale. The major purpose of the study was to establish the extent of teachers' use of instructional resources in teaching pre-primary science and mathematics activities in Athi-River Sub County of Machakos County, Kenya. The study also found out the effects of teachers' training level in the use of instructional resources in teaching science and mathematics, Teacher-gender and use of instructional resources, Teacher's attitude and use of instructional resources in teaching science and mathematics activities and teacher-motivation on the use of instructional resources in teaching science and mathematics in pre-primary schools. This study employed Bruner's learning theory (1966), which matched well with the determinants of pre-primary teachers' use of instructional resource. The study targeted 40 pre-primary head teachers, 600 pre-primary teachers and 1800 pre-primary children in Athi-River Sub-County, Machakos County. Athi-River Sub-County was sub-divided to 5 bases and stratified sampling technique was used to select 6 pre-schools from each base translating to a total of 30 pre-schools. Random sampling was used to select 6 pupils from each of the sampled schools for focused study giving a sample size of 1800 pupils. Purposive sampling was also used to select 2 teachers for science and mathematics activities from each of the sampled schools. All head teachers from all the 30 sampled schools were selected leading to a sample of 30 head teachers. A sample size of 270 respondents including 60 teachers, 30 head teachers and 180 pupils) was used in the study. Questionnaires and oral-interviews were used to collect data. Validity of the instruments was determined through examining of the items using content validity. A. Pilot test of the research instruments was done in two schools in the neighboring sub county. Quantitative data was generated from the close-ended items from the questionnaires. Descriptive statistics was used to analyze data such as frequency; standard deviation and mean data analysis was analyzed according. The data was presented in tables. Qualitative data produced from the questionnaire, interview schedules, focused group discussion, as well as data obtained through the observation checklists was analyzed with regards to relevant themes and discussed in line with the research objectives. The findings of the study were as follows: teachers with higher training qualifications were more likely to use instructional resources in teaching science and mathematical activities than their counterparts with less or no training. Male teachers were found to use instructional resources more often in teaching science and mathematics than their female counterparts. Teachers with positive attitude towards science and mathematics were also found to use more instructional resources than teachers with negative attitude. The study recommends that the 
ministry of education should facilitate pre-primary school teachers to advance their studies through in-service training and that the government of Kenya should motivate pre-primary teachers by paying them reasonable salary. All stakeholders should ensure that instructional resources are made available for better pupil achievement in science and mathematics.

Key Words: Teachers' Use of Instructional Resource, Teaching Pre-Primary School Science, Mathematics Activities, Machakos County

DOI: 10.7176/ijcab.v3iII.16, urn:nbn:de:0000ijcab.v3iII.165

\section{Cite this Article:}

Ayiema, J., \& Mwoma, T. (2019). Determinants of Teachers' Use of Instructional Resource in Teaching Pre-Primary School Science and Mathematics Activities In Machakos County, Kenya. International Journal of Current Aspects, 3(II), 158-184. http://journals.ijcab.org/journals/index.php/ijcab/article/view/16

\section{INTRODUCTION}

Instructional resources especially in the teaching of science and mathematics is vital in instruction process according to Oladejo, Olosunde, Ojebisi \& Isola, (2011) since they have the potential of helping the teacher explain new concepts clearly Okobia (2011) identified that instructional resources results in better understanding and aid the teacher in the effective transfer of knowledge to learners.Karaka \& Fabian, (2007) said that instructional resources add value in class performance and upsurges the attainment of content learned as by Baylor and Ritchie( 2002).Eison,(2010).recommended that instructional resource helps in enhancing retention which makes learning more permanent and reliable for the learners in early childhood levels. Instructional resources stimulate and sustain interest in learning by providing first-hand experience with the realities of the physical and social environment of the child. Finally, Sapir (2011) suggests that the use of instructional resources assists children in opening up all developmental aspects leading to holistic learning process. It has been observed that children who are exposed to various instructional resources are actively and better involved in the learning process according to Hattie, \& Yates (2013). In Kenya pre-primary school centers are the receiver of the innocent innate children as they transit from home to school. Hirst, Jewis, Sojo and Cavagh (2011) suggests that pre -primary school is basis for learning and it helps children to develop skills, knowledge, personal competence, confidence and a sense of social responsibility. As children move to school, they need to adapt to the new environment which they meet and environment ought to be favorable and rich of instructional resource. Instructional resources encourage children to like schooling and also make learning experiences interesting and enjoyable. Therefore, teaching becomes easier with the use of instructional resources in pre-school .Afshari (2009) and Hirst (2011) found that the use of instructional resources in pre-primary schools had a greater value to all children in learning of science and mathematics.

Loucks -Horsley (2009), stated that Science and mathematics are essential for the development of any nation. According to Banilower (2013), learning of science and mathematics enables learners to understand their environment and solve their daily life problems. At Early Childhood Development (ECD) level, science and mathematics refers to basic concepts, skills and attitudes that enhance children's understanding of the natural environment, Charles worth (2015). The use of instructional resources in teaching science and mathematics therefore enables learners to explore basic scientific and mathematical skills of observation, manipulation, 
classification,communication, designing experiments, measurement, hypothesis, predictions, problem-solving, recording, and questioning of the events Ministry of Education, Science and Technology (MoEST)(2008). Young children are naturally curious which makes their interaction with nature and learning experience and hence the presence of instruction resources in pre-school cannot overstated. Children are inherently, mathematical and scientific minded hence it is essential to provide a conducive and stimulating environment rich of instructional resources so as to enhance their inherent potential according to National Research Council, (2009). The scientific and mathematical process of curiosity, discovery, experimentation, measurement and organization of information and reporting builds positive attitudes towards studying science and mathematics among children.

Catchan (2013) said in his study that teaching of science and mathematics are very important in any educational systems which leads to modern development of any growing county in order to achieve vision 2030. Alot states have brought ideas on the performance of science and mathematics which has created( STEM) sciences and mathematics. The creation of Science, Technology, Engineering and Mathematics, this creation was made for all children to learn effectively for better future of the nation.. There came a proposal to improve STEM by coming up with (STEAM) Science, Technology, Engineering, Arts - Language, Visual and Performing - and Mathematics to create innovation and creativity in children as they enjoy learning science and mathematics. In 2007, the government of Kenya in concurrence with World Bank international monetary fund and Japanese instigated Strengthening Mathematics and Science in Secondary Education (SMASSE) so as to increase science and mathematics. This implied that science and mathematics had a problem in the curriculum that desirable to be spoken properly, the current study has originate out that the teachers' use of teaching resources will mechanically promote science and mathematics activities. The importance of pre-primary teachers' use of instructional resources in teaching science and mathematics activities provides skills, knowledge and competence to the children's learning process as by Lampert( 2010) and provides stimulating environment in the learning process. When instruction resources are effectively used by teachers in science and mathematics activities, they make children to create stimulating interaction with them, hence automatically promoting children's academic achievements as stated by Shonkoff and Philips( 2013).

Harris and Sass (2009) established that teachers with a standard certification had a statistically significant positive impact on student test scores relative to teachers who either held private school certification or were not certified in their subject area. This study showed that teachers' training has an impact on the teaching methods, use of instructional resources and content knowledge which are key for children achievement. Kosgei, Mise, Odera, and Ayugi (2013) investigated the influence of teachers' experience and qualification on students' academic achievement in Biology. The study findings showed that $80 \%$ of teachers who participated in professional development programs such as SMASSE showed better and improved student performance. Eccles and Wigfield (2002) noted that the sex of ateacher influences and motivates children's abilities as it results good academic achievement. Kueckeny and Valfortz (2012) did a study on the relationship and interaction between the sexes of a teacher on learning outcomes. The study result established that both male and female pupils performed better in reading when taught by female teachers than male teachers while learners performed better in mathematics with male teachers. This study sought to establish the influence of teachers' sex on the use of teaching and learning materials. Odunaike, Ijaduola and Amoda (2013). The study found that female teachers gives a lot of energy in supporting children in order to improve their academic performance as compared with male 
teachers who takes teaching as a profession for the females. Another study by Okoro, Ekanem and Udoh(2012), investigated the result of teacher masculinity on the academic realization and presentation of children in primary schools in Uyo Metropolis -Nigeria. The results displayed that teacher-pupil sex connections meaningfully exaggerated pupil's educational performance.

There are mixed findings on the relationship between teachers' use of instructional resources and educational practice. Some studies show that the use of instructional resources is associated with higher educational achievement in pre-primary school. Ng'asike (2012) did a study on training of science teachers for early childhood and primary grade in Kenya and discovered that though the government of Kenya emphasizes science as critical subject for advancement of technologies and attainment of the vision 2030 science activities and resources are not yet offered in the trainings to meet the demands of science for understanding knowledge and logical thinking. This implies that there is still lack of information on proper utilization of instructional resources among teachers at all level of learning since there is minimum scientific training on the use of these resources in instruction. According to Pramling and Samuelsson (2010) realized that increasing teacher education does not produce as good academic accomplishments as the suitable use of teaching/learnin resources among the teachers. The use of instructional resources successfully contribute toward positive academic accomplishments. Similarly, Hiebert \& Grouws (2007) stated that science and mathematics teaching-learning activities depend on teaching and 1 earning aids or use of instructional resources and teaching methods used by young children which makes learning to be more interesting and enjoyable in the class environment, study by Ngololo (2012) in Namibia, found that teachers' competencies in mastering the curriculum contents wasted the subjects due to deficiency of teachers, inadequacy of instructional resources and poor teaching approaches. Reviewing the vast body of knowledge on the characteristics of teachers and their influence on learner presentation, this study takes advantage of the huge gap on pre-school especially on issues that guidance the teachers' selection, implementation and consumption of instructional resources in teaching science and mathematics activities among pre-school children in Athi River Subcounty of Machakos County Kenya .

\section{STATEMENT OF THE PROBLEM}

When teaching science and mathematics, early childhood teachers have tremendous impact and influence on shaping the thoughts and opinions of children Clements \& Sarama,(2014). Research shows that most children have formed an opinion (either positive or negative) about science and mathematics by the time they reach the age of seven years stated Hattie \& Yates (, 2013). That puts a tremendous responsibility on early childhood professionals, especially with all of the emphasis being placed on STEM education. Sarama and Clements (2009) asserts that children who are taught math early and learn the basics at a young age are set up for a lifetime of achievement in all aspects of their academic performance. Considering the known importance of mathematics and science in the society, it's important to carry out studies that are geared toward their improvement in our schools. An analysis of Kenya Certificate of Primary Education (KCPE) results from 2012 to 2015 show a downward trend in performance of science and mathematics in Athi River Sub-County (District Education Officer - Athi- River, 2015). The results show that the performance of Science is below average. The introduction of the Strengthening Mathematics and Science Education (SMASE) and SMASSE with a view to improve student achievement has not achieved much. Furthermore, most of the teachers who are allowed to attend these forum are high school teachers yet the requisite knowledge and the basis in mathematics and sciences is laid at pre-school level hence there is need for preschool teachers to be given priority. 
In Athi River Early Childhood Development and Education (ECDE) has been left to parents resulting to poor and adequate science and mathematics instructional resources. Other than the availability, appropriateness and adequacy of the instructional resources in preschools, their use for instructions by teachers is key in ensuring that children's achievements in science and mathematics activities are assured. However, performance related studies have focused on teacher professional characteristics (Ng'asike,( 2012), teacher training (Goldhaber \& Brewer, (2000); Harris \& Sass, (2011), teacher education and experience (Zhang,(( 2008), availability and adequacy of teaching and learning materials (Czerniewicz \& Brown, (2005). None of the studies focused on influence of the use of the instructional resources by the teachers on learner performance. Furthermore, most of the studies have focused on primary and secondary schools yet these factors established at pre-school level can help to avoid performance issues at higher levels. This study took advantage of this gap to seek the use of instructional resources and teachers' characteristics and determine the use of these resources in teaching science and mathematics activities among pre-school teachers.

\section{OBJECTIVES OF THE STUDY}

The study sought to achieve the following objectives;

i) To establish the extend of use of instructional resources in teaching science and mathematics activities among pre-primary school teachers in Athi-River sub-county.

ii) To establish how teachers' training levels affect the use of instructional resources in teaching Science and Mathematics activities in pre-primary teachers.

\subsection{REVIEW OF RELATED LITERATURE}

\subsection{Instructional Resources in teaching Science and Mathematics}

Use of Instructional resources in teaching science and mathematics is vital in improving the academic achievement of the young children. A study done by Mwong and Wanyama (2012) discovered that teaching and learning resources not only enhances a Child's acquisition of science and mathematics skills but also ensures good and smooth transition from preprimary to primary school. Muithungu, (2003) supposed that teachers should use many of teaching/learning resources locally found within their local environment to avoid purchasing instructional resources which are very expensive for teaching and learning in the preprimary schools. Parents have the responsibilities to ensure that all the required learning and teaching instructional resources are available in all the pre-primary schools for children to without any tricky. Muithungu (2003) recommended that the teacher is the major driving source of instructional resources and he/she has to influence children and parents to provide or collect the teaching and learning resources to use during the mathematics and science activities. Muithungu, further adds that teaching and learning resources can be made available by parents and the community as a whole for the ECDE centers within the locality. This can be successfully done by organizing for material development day in school. The community members and parents can collect and others can donate to the school, meet and share thus encouraging early enrolment and learn to provide learning resources.

A study on the approaches to young children's science and mathematics concepts and scientific problem-solving skills on the classroom environment found that there were moderating effects of classroom surroundings on the application of science and mathematics concepts. This findings of the study used theories of both Vygoskey and Piaget and it was done in Indiana by Colgrove (2012), while the current study was conducted in Athi-River and used only Bruner's learning 
theory in the theoretical framework, and its focuses were on the determinants of pre-primary school teachers' use of instructional resources in teaching science and mathematics activities. Australia in 2003. In 2006, over the full range of primary school experience, science occupied 45 minutes per week (3\% of an average teaching week of 1486 minutes) while mathematics occupied 263 minutes (18\% of an average week according to the study done by Angus, Olney \& Ainley, (2007).The findings of the study revealed that science was not adequately utilized in the schools teaching learning processes.

In Bangladesh, Mondal (2011) did a study on teaching practices on Biology in rural and urban secondary schools. The study found that there was a difference in teaching/learning materials in urban and rural in teaching biology. Biology is a science study which was also done in secondary level, while the current study was based on pre - primary school level and the study sought to investigate the use of instructional resources by pre-primary school teachers in teaching science and mathematics activities in Athi-river sub-county of Machakos county Kenya. In India, Bartsch (2009) established that the use of teaching and learning resources can be relevant in teaching science in schools. The study was similar to the current but this was done in India and the study focused on only science activities contrary to the current study which was conducted in Athi-River, Machakos County, Kenya on pre-primary school and focused on the determinants of pre-primary school teachers" use of instructional resources in teaching science and mathematics activities in order to solve the poor performance of science and mathematics in Athi-River Sub -county Kenya. Okobia (2011) required to judge the obtainability and teachers' use of teaching/ learning materials and resources in the application of junior secondary school social studies curriculum in Edo state. A sample of fifty social studies teachers were randomly designated from fifty junior secondary schools in five local government areas of Edo State. Data analysis was agreed out using t-test for the hypothesis and simple percentages for questions one and two. The outcomes exhibited that teaching/ learning materials and resources accessible were grossly insufficient. It was also perceived that there was no variance in the use of teaching/learning materials between expert social studies teachers and non-specialist teachers. It is therefore suggested that instructional materials and resources be made available for the teaching of social studies.

In Kenya, studies done by Ogolla (2015) on the relationship between teaching and learning materials on performance in KCSE in Nyakach found that biology has been poorly done over five years. Yes, biology is a science but taught in secondary schools; on contrary the current study which focused on the use of teaching and learning resources in teaching science and mathematics activities in pre-primary schools in Athi-River not Nyakach which has a different demographic zone. Ambogo (2012), in his study on effects learning equipment on chemistry found out that there was significance correlation between KCSE Performance in science and availability of learning materials or equipment, the study was focusing the poor performance of science but in the secondary level, while the current study's focuses on preschool level and on science and mathematics activities. In 2007 the government of Kenya in conjunction with World Bank, international monetary fund and Japanese initiated SMASSE to strengthening mathematics and science in secondary education. There is need to focuses on the improvements of science from preschools which the focuses the basic of science. Mutai (2006) suggested that learning is strengthened when there are enough teaching and learning materials which increase academic achievements, the study seemed to be similar to current studied study on determinant of teachers' use of instructional resources in teaching science and mathematics activities, but, Mutai focused on the performance of the KCPE. There is need therefore to study the topic determinant of 
teachers' use of instructional resources in teaching science and mathematics in pre-primary schools to whether there was any difference between primary and pre-primary school on the use of instructional resources in teaching of science and mathematics activities. The use of computer and internet applications are technologies used in today's teaching/learning, but there is need for skills and knowledge of the teacher to apply in teaching according to the claim by, Butera, Czaja, Harison, Liberal \& Plamer (2009).

In science and mathematics activities, children learn physical science which are the study of energy, light, measurement, heat movement and change in early childhood (Allen, 2002). Preprimary school teachers should use instructional resources in teaching and learning of science and mathematics activities, the science activities involved are; observation, investigation, measurement and communication on the results and therefore there was a need to use materials in teaching science and mathematics as the case study. Wanyonyi, and Makokha, (2015) also investigated the utilization of instructional resources by Kiswahili teachers in the teaching of poetry in secondary schools in Nandi North Sub - County. This was guided by the operant conditioning theory, the study used systematic sampling to select 20 Kiswahili teachers in secondary schools in the sub-county. Using questionnaire, observation and interview schedule to collect data, the study established that secondary schools in the study area had good facilities and resources. The study further revealed that poor performance in Kiswahili poetry was contributed by poor and inadequate utilization of instructional resources among teachers. The study recommended that there was need for teachers to utilize instructional resources in teaching Kiswahili poetry to enhance the amount of information a student could learn and retain. The current study investigated characteristics of teachers that influence the utilization of instructional resources in teaching mathematics and sciences in pre-schools. Bitengo (2005), in his research findings on preschool teacher's age towards the teaching of mathematics in Kasarani division in Nairobi found that there is a significant relationship between the teacher's characteristics, content, instructional resources, learning activities, individual differences among children and the objectives to be achieved at the end of the learning process. Ndani (2006) observed that learning in preschools is due to better and an enriched environment with variety of learning materials. Therefore the presence or absence of learning materials distinguish between high and low achievement in children's learning.

\subsection{Teachers Level of Training and Use of Instructional Resources}

A study done by Westbury (2000) distinguishes the teacher as the agent of curriculum application. Fullan (2014) claims that the reputation of the teacher as a central change agent, as the teacher is the one who is primarily accountable for the fruitful execution of a new curriculum. According to Morrison, Bachman, \& Connor (2005) the teacher's teaching, classroom organisation tactics, and connections with students at classroom level can define how much is learned or trained for the same profession. A study by Brill \& McCartney (2008) discovered that lack of teachers training and poor teacher retention as key barriers to current curriculum execution. The key to getting teachers devoted to modernisation is to improve their information of the program. This means teachers need to be trained and workshops organized for professional development. Certainly an satisfactory teacher education program should include curriculum development if teaching is to be a profession and if opportunities for learners are actually to be better-quality. Content knowledge aside, it is only when a teacher can connect excellently that he will be able to draw upon the various social cultural contexts of the learner to facilitate learning according to Tsui(2001). Actual classroom communication can also be improved by specific attention of teachers to their scholars. 
Teacher trainings has countless effect on the use of teaching resources in teaching science and mathematics and automatically stimulates children 'successes. Teacher trainings are related to children's successes. Goe, (2007); Rice, (2003) and Zeichner \& Conklin, (2005) came up with their uniform test scores to find on the joining between teacher credentials and children's presentation, the extent of the joining between teacher trainings and any learner's performance, are predisposed by attendance or grades, which was generally beyond the scope of this study. Some developing countries have started computer literacy training for teachers, which has led to a vibrant reason for partaking ICT in education; however, it is prominent that effective training should not stop at computer literacy but should model real teaching applies. Infodev,( 2015), Nonetheless, noted that there are many other countries that provide slight or trivial teacher training connected to ICT in education. For example, hint from Europe shows that $70 \%$ and $65 \%$ of children in Lithuania and Romania, correspondingly, are taught by teachers for whom it is necessary to participate in ICT training, compared to just 13\% or fewer of students in Luxembourg, Austria and Italy (European Commission, 2013).

Learning might also appear and be strengthened through apps that arouse the use of many senses, according to Carr, (2012), which is usually done through the use of teaching and learning by the use of instructional resources. With mobile devices such as smart phones, there is direct collaboration with the wonders, rather than being facilitated through a mouse or keyboard, making the iPad more fit for children than desktop computers as discussed by Sinclair and HeydMetzuyanim, (2014). Use of instructional resources in teaching science and mathematics is required for children to recall perceptions properly throughout the learning process. Hegedus, (2013). Proposed that this app also educes multi-touch functionality, enabling children to make sense of single belongings of particular instructional resources therefore very necessary for teachers to train on the correct use of instructional resources for better teaching to be realized. The affordances of instructional resources in teaching of science and mathematics activities shall led to cognitive risks and make it very difficult to achieve the expected objectives from the learner's feedback activities. Calder and Campbell, (2016). The instructional resources allow children to model in a dynamic, reflective way. According to Meyer (2015) established that instructional resources provides new forms of personal ownership that in turn supports children's personal understanding and conceptual frames as they learn science or mathematics activities. Melhuish and Falloon, (2010),stated that the problem of lack of qualified teachers has been renowned in the teaching professional.

A study by Yeboah-Appiagyei, Joseph, \& Fentim (2014) on the effects of professional qualifications of financial accounting on academic performance in Ghana, revealed that teachers with sound training were equipped with the requisite competence that enable them to harvest real package in teaching associated to less trained teachers. In South Africa, Mathevu (2014) did a study on the effect of trained teacher use of computer; Data were composed in research using questionnaires from 146 participants in twelve secondary schools located in the Groot Letaba Circuit, Mopani District Municipality in Limpopo Province, South Africa. The findings exposed that with the exemption of a TVs, photocopiers and laptop/desktop computers, there is a scarcity of ICT resources available at schools. Most teachers have been negatively affected by a lack ICT equipment and/or deficient use of these ICT resources but well trained teachers have skills and assurance to use ICT and any other learning resources in their teaching (Summak, Samancioglu, Goyal, Purohit \& Bhaga, 2011). This was a study done in South Africa, but the current study was done in Athi-River sub county of Machakos in Kenya and the focus was how pre-primary teacher 
use of instructional resources in teaching science and mathematics activities in preschools. Currently, a major issue is intensifying the dynamics of the public schools. Most children are increasingly reflecting negative attitudes towards learning especially as they move from lower class or grade to another in search of knowledge.

Jenkins, Floress and Reinke (2015) in their study sought to found how teachers are encouraged in the use of instructional resources in teaching science and mathematics and the wish for children to use resources for operative teaching in schools. In pre-primary schools there is about $95 \%$ satisfaction; and then it goes steadily down until it bottoms out in standard eight at $37 \%$. This represents a wonderful extent of bored children. For teachers one could say that there is only one thing worse than being bored. Moreover, the last two Met-Life surveys (2008 and 2010) have shown an intense decline in teacher satisfaction, reducing from some $54 \%$ to $40 \%$ or less. Thus, school, as it is currently planned and experienced, is mentally and literally "pushing" students and teachers out of school. Information and announcement technology (ICT) has the likely to alter teaching and learning processes. However, most countries expression tasks in computing the influence of savings in set-up, enormous roll-outs of teacher training ingenuities, and usage in the classroom. The lack of a complete set of needles can somewhat clarify current tasks. Moreover, there is a mounting acknowledgement that additional focus is needed to measure teacher training and usage holistically within a systems standpoint whereby needles are not viewed in separation but reflect a complex pattern of how teachers are set and how teaching activities with pupils, in and out schools and the classroom are implemented (Partnership on Measuring ICT for Development, 2010). Following a technical advisory panel (TAP) meeting that carried calm a various group of mathematicians and theme material professionals in the area of ICT in education from 9 to 10 December 2014 in Paris (France), this paper has been developed to help reinforce the theoretical framework of ICT in education with specific reference to the importance of collecting data relevant to teacher training in relation to ICT and its usage in the classroom. This paper is complementary to a paper authored by Broadley, Downie and Gibson (2015) on 'Evolving Learning Paradigms' and 'Developing new indicators to describe digital technology infrastructure in primary and secondary education'. These three papers were custom-built by UIS to inform the preparation of new ICT in teaching data get-togethers and finding core signs for the post-2015 developmental agenda.

The UNESCO-UIS Guide to Computing Data and Communication Technologies (ICT) in Education, Technical Paper No. 2 (UIS, 2009), put in place a shared set of unchanging globally settled pointers on ICT in teaching with a number related to teachers' expert growth and rehearsal, which are fatigued from administrative sources. This paper however argues that a more complete method, as per example the ICT Education 2013 Survey (CETIC. Br, 2013) on the use of ICT in Brazilian schools, may be useful for shedding additional light on teacher dimensions of ICT in education. More specifically, this paper tries to measure present pointer gaps in teacher specialised expansion and training by asking elementary questions, including who is being trained in the use of ICTs, where and how are teachers trained, what kind of ICT training is if and founded on which certification standards, and finally, when and for how long are teachers trained? Built on a study of these problems, extra gauges are recommended. This paper also scrutinises teacher practise of ICT in conveying instruction and makes a case for including cross-cutting elements that point to teachers' usage of ICT-enhanced pedagogy, digital curriculum and charge, ICT in instruction policy, ICT structure, and ICT used for structural and administrative purposes. The schooling of simple computer skills and computing was also addressed. 
On enhancing the competence of electronics teachers in the utilization of instructional resources for effective electronics subject delivery which has been reported by Okwelle, and Allagoa, (2014) as lacking among secondary school technology teachers and according to Nigeria. Okwelle, and Allagoa, (2014) study recognized that difficulties related with the actual use of these teaching/learning resources in secondary schools such as poor teachers' qualified knowledge and inadequate mindfulness of kinds of instructional materials for use in instructing diverse electronics contents, were highlighted. Also, the electronics teachers emerging optimistic defiance towards the use of instructional materials; keeping correctness of the materials to instructional objectives and multidimensional exhibitions of these materials among others, were strategies hypothesised for enhancing teachers' ability in instructional material utilization. Lastly, the rank of obtaining better gender-related statistics regarding teacher exercise and usage of ICT in education, including indicators influenced by sex, is highlighted. digital curriculum and assessment seem to be mostly applicable in countries at more advanced stages of ICT development, various digital materials are gradually accessible for use, while Open Education Resources (OER) are also progressively existing for re-use and variation within evolving countries. Open Educational Resources (OERs) are any kind of instructive materials that are in the public field or familiarized with an open license. The nature of these open materials means that anyone can legally and freely copy, use, adapt and re-share them. OERs range from textbooks to curricula, syllabi, lecture notes, assignments, tests, projects, audio, video and animation (UNESCO, 2015b). The cumulative obtainability of OERs do not essentially render into use by teachers. For example, in Europe it is conveyed that $15 \%$ of students in all grades are taught by teachers announcing that they create digital incomes almost every day, and about an additional 15\% at least once a week (European Commission, 2013).

\section{RESEARCH METHODOLOGY}

The study applied descriptive survey research design with both qualitative and quantitative approaches. This approach to research enabled the study to gather adequate information that provided better understanding of the research problem and answering the entire research questions than using either qualitative or quantitative research approach alone according to Creswell and Plano Clark( 2011). This research design was chosen because it enabled the researcher to explore, collect and explain in-depth empirical data about determinants of Pre-Primary School Teachers' Use of Instructional Resources in Teaching of Science and Mathematics Activities in Athi-River, Machakos County Kenya. The researcher also preferred the descriptive research design since it is broad-based. This implies that it enabled the researcher to collect primary data from a diverse category of subjects. Interviews, questionnaires and observations were the main tools used for collecting data. The study was done in Athi River Sub-County, one of the eight Sub-Counties in Machakos County in the Eastern Kenya. The sub-county has four wards namely Athi River Town, Katani/Muthwani, Kinanie/Mathatani and Syokimau/Mlolongo. The sub-county has 19 locations and 39 sub-locations. The economic mainstay for Athi River Sub-County is agriculture, mining, fruit farming and poultry keeping. Therefore, $70 \%$ of the population is employed in agricultural activities with very low incomes. Levels of poverty are high where children engage in mining to supplement family income. Due to this poverty index and involvement of children in various forms of child labour, the access to education is hampered and this may even influence appropriate utilization k2of instructional materials for teaching science and mathematics in preschools.

Despite the fact that most households in the sub-county depend on small scale agriculture and mining as the main source of livelihood, the sector faces a number of constraints which, unless removed continued to work against poverty reduction efforts. Some of these include the high 
incidences of HIV/AIDS which has led to the loss of life and depletion and diversion of badly needed family incomes, un-economical subdivision of land due to the high population pressure, low agricultural productivity, unaffordable input prices that discourage farmers from investing in agriculture and unstable cash crop prices. This situation is further aggravated by landlessness among women and youth, and mismanagement and near collapse of cooperative societies especially coffee and pyrethrum and poor agricultural produce marketing. The low level of human resource development is one of the causes of poverty in the sub county. For most people, the cost of education is too high therefore the level of literacy is quite low. This coupled with the fact that further education and training are hampered by the limited number of institutions and low quality of education acquired from them, meaning that the population particularly the labour force is not well equipped to compete effectively in the local job market and therefore the ability to secure remunerative jobs or other income generating opportunities (GDP, 2002-2008).

This area was chosen for the study because of its photographical presentations of both rural and urban settings and it clearly presented the approximate picture of Kenya and accordingly to ministry of education monitoring report (2015) the performance of science and mathematics in both primary and secondary schools in Athi river sub county was poorly done and therefore the researcher wanted to investigate whether the use of instructional resources in teaching science and mathematics activities may be the cause or not. The prevailing trend of poor performance of science and mathematics in the sub-county made it necessary for the research to choose the location. The study targeted teachers in 40 public pre-primary schools in Athi-River Sub-County, Machakos County. A purposeful sampling was used to select Athi-River Sub-County, among other seven Sub-Counties of Machakos namely; Machakos, Kathiani, Mwala, Kangundo, Matungulu, Yatta and Masinga because Athi-river has unique locations or sites for the intended study to be applicable more appropriately. Athi-River Sub-County was sub-divided to 5 bases and a stratified sampling technique was used to select 6 pre-schools from each base translating to a total of 30 preschools. Creswell (2005) states that in stratified sampling, researchers divide (stratify) the population on some specific characteristics and then randomly sample from each sub-group of the population. This guarantees that the sample included specific characteristics that the researcher wants included in the sample. Stratification ensures that the stratum was represented in the sample in proportion to that in the population. The schools were stratified into public and private primary schools and also according to bases in Athi River Sub County.

Random sampling was used to select 6 pupils for focused group discussion, from each sampled school leading to a sample of 180 pupils. Random sampling method helped the researcher to give all subjects equal chances to be selected for the study. Purposive sampling was used to select 2 teachers teaching science and mathematics activities from each sampled school and all the 30 head teachers from all the sampled schools leading to a sample of 60 teachers and 30 head teachers respectively. Purposive sampling technique was appropriate to enable all the key respondents to take part in the study. The sample size of the study were 5 public rural schools, 10 private rural schools, 5 public urban schools and 10 private urban pre-primary school centers in Athi-River SubCounty of Machakos. A sample size of 270 respondents (30 head teachers, 180 pupils and 60 teachers) were included in the study. The selection of these tools was guided by the nature of the data collected, time available, as well as the objectives of the study. The researcher used the following instruments for effective analyses to be realized that was; questionnaires and oralinterviews. The study used a questionnaires comprising of both open and closed ended questions in line with the mixed methods approach. The open-ended questions gave respondents freedom of 
response and captured qualitative data. The closed ended questions facilitated consistency of certain data across respondents and were quantitative. The questionnaire was utilized to capture data from pre-primary school teachers who had no problem or difficulties in responding to questionnaire items. Additionally, questionnaires are popular in data collection because of their relative ease and cost-effectiveness with which they were constructed and administered.

Interviews involved conversations that were used to gain personal information, knowledge, attitudes or opinions from a list of prepared questions asked to each participant in the same manner. Head teachers of the sampled schools were interviewed to gather information on determinants of Pre-Primary School Teachers' Use of Instructional Resources in Teaching of Science and Mathematics Activities in Athi-River, Machakos County Kenya. Head teachers were interviewed to understand their diverse opinions about determinants of Pre-Primary School Teachers' Use of Instructional Resources. A set list of structured and unstructured questions was used to interview the head teachers on determinants of Pre-Primary School Teachers' Use of Instructional Resources in Teaching of Science and Mathematics Activities. Interview schedules were prepared in advance and these were conducted on the selected head teachers. The semi-structured interview involved the interviewer initiating questions and probes were used in responding to interviewee's descriptions while structured interview involved the Interviewer following scripted questions and no deviation from question order. The semi-structured interview was appropriate for the study because the language Level of the respondents could be adjusted, Interviewer could answer questions and make clarifications, the researcher could prompt and probe deeper into the given situation, the interviewer was able to probe or ask more detailed questions, situations and not adhere only to the interview guide but the researcher could explain or rephrase the questions whenever respondents were unclear about the questions. Structured interview was also appropriate for the study because the researcher had control over the topics and the format of the interview by the use of a detailed common interview guide, which made it easier to analyze code and compare data. Ader, Van, Deltaan and Beekman, (2008) reiterate that the interviews was to solicit data concerned with views, perceptions, and feelings about the implication of the use of instructional resources in teaching science and mathematics activities. In this study, in depth interviews was conducted to collect the required information from the sampled pre-school head teachers. The data were gathered from interview schedule to help to authenticate data acqk2uired through questionnaire. This study preferred to use interview schedule because an interview schedule provided a free environment for the respondents to express themselves and even gave rise to further information which was not catered for in a questionnaire. All interviews were recorded and transcribed for analysis purposes, with the consent of the respondents.

Focused Group Discussions assisted in determining detailed information about personal feelings, perceptions and opinions of teachers and the kind of instructional resources they used for teaching. The use of focus group discussion was cheap compared to conducting individual interview and it also offered an opportunity for the respondents to seek clarification on various issues. Observation checklist was used where it was impossible to collect data using interviews or questionnaires, such as when participants were young children like the case in the current study. For the above reasons, observation checklist was used for direct observation of the pre-primary teachers use of instructional resources in teaching science and mathematics activities, and to check whether conditions in pre-school in terms of application for materials and its environment was encouraged, productive and engagement or not. Kombo and Tromp (2006) argue that direct observation presents data in its natural form, making the observer an active participant in the study and permits 
time to think about what is occurring rather than on how to record it. Quantitative data was first coded and entered into the computer for analysis using the Statistical Package for Social Sciences (SPSS) version 22.0. The descriptive statistics that was used include frequency counts and percentages. The purpose of descriptive statistics enabled the researcher to meaningfully describe a distribution of scores or measurements using a few indices as was stated by Mugenda and Mugenda (2010). This enabled the researcher to transform large groups of data into a more manageable form that was easy to understand and interpret by Mbwesa( 2006).

Transcripts were read carefully. They were then coded into themes in relation to the research questions and information collected by Gerstenfeld and Berger, (2011). Then a list of all topics was made and sorted according to similarities and differences using highlighters of different colours. The topics were later abbreviated as codes and the codes written near the related text in word document. Then these topics were turned into categories - major topics, unique topics, leftovers and emerging themes. Finally, the information assembled according to category and a preliminary analysis was made and adapted from Creswell (, 2009). The categories were developed from both the data and research questions based on theory and determined at the formulation of the research instrument. The sub-themes were mostly developed from the data. The data from questionnaires, interviews and observation were also sorted according to themes. Therefore, interpretational analysis largely examined carefully so as to find constructs, themes and patterns that were useful in understanding the phenomenon under study. Above all, the researcher tried by all means to make sense of the meanings that the respondents attached to the phenomenon just like argued by Cohen et al., (2007). This was a challenging task but through reading books and Consulting the two supervisors, a meaningful analysis was made.

Table 1: Quantitative Data Analysis Framework

\begin{tabular}{|c|c|c|c|}
\hline Objectives & $\begin{array}{l}\text { Independent } \\
\text { Variables }\end{array}$ & Dependent Variables & $\begin{array}{l}\text { Method } \\
\text { Analysis }\end{array}$ \\
\hline $\begin{array}{l}\text { To establish the extent of } \\
\text { teacher's use of } \\
\text { instructional resources in } \\
\text { teaching science and } \\
\text { mathematics in pre- } \\
\text { primary schools in Athi - } \\
\text { River sub-county. }\end{array}$ & $\begin{array}{l}\text { Extent of } \\
\text { usage of } \\
\text { instructional } \\
\text { resources }\end{array}$ & $\begin{array}{l}\text { Use Of Instructional } \\
\text { Resources In Teaching } \\
\text { Science And Mathematics } \\
\text { Across Pre-Primary School }\end{array}$ & $\begin{array}{l}\text { Frequency } \\
\text { counts and } \\
\text { percentages }\end{array}$ \\
\hline $\begin{array}{l}\text { To find out if there is a } \\
\text { difference in the use of } \\
\text { instructional resources in } \\
\text { teaching science and } \\
\text { mathematics across pre- } \\
\text { primary school teachers' } \\
\text { level of training. }\end{array}$ & $\begin{array}{l}\text { Teachers' } \\
\text { level of } \\
\text { training. }\end{array}$ & $\begin{array}{l}\text { Use of instructional } \\
\text { resources in teaching } \\
\text { science and mathematics } \\
\text { across pre-primary school }\end{array}$ & $\begin{array}{ll}\text { Frequency } & \\
\text { counts } & \text { and } \\
\text { percentages } & \text { and } \\
\text { regression } & \\
\text { analysis } & \end{array}$ \\
\hline $\begin{array}{l}\text { To find out if there is a } \\
\text { difference in the use of } \\
\text { instructional resources in } \\
\text { teaching science and } \\
\text { mathematics between male }\end{array}$ & Gender & $\begin{array}{l}\text { Use Of Instructional } \\
\text { Resources In Teaching } \\
\text { Science And Mathematics } \\
\text { Across Pre-Primary School }\end{array}$ & $\begin{array}{ll}\text { Frequency } & \\
\text { counts } & \text { and } \\
\text { percentages } & \text { and } \\
\text { regression } & \\
\text { analysis } & \\
\end{array}$ \\
\hline
\end{tabular}




\begin{tabular}{|c|c|c|c|}
\hline Objectives & $\begin{array}{l}\text { Independent } \\
\text { Variables }\end{array}$ & Dependent Variables & $\begin{array}{l}\text { Method } \\
\text { Analysis }\end{array}$ \\
\hline \multicolumn{4}{|l|}{$\begin{array}{l}\text { and female pre-primary } \\
\text { school teachers. }\end{array}$} \\
\hline $\begin{array}{l}\text { To investigate the } \\
\text { relationship between } \\
\text { teachers' attitude towards } \\
\text { instructional resources and } \\
\text { use of instructional } \\
\text { resources in teaching } \\
\text { science and mathematics. }\end{array}$ & $\begin{array}{l}\text { Teachers' } \\
\text { attitude }\end{array}$ & $\begin{array}{l}\text { Use Of Instructional } \\
\text { Resources In Teaching } \\
\text { Science And Mathematics } \\
\text { Across Pre-Primary School }\end{array}$ & $\begin{array}{ll}\text { Frequency } & \\
\text { counts } & \text { and } \\
\text { percentages } & \text { and } \\
\text { regression } & \\
\text { analysis } & \end{array}$ \\
\hline $\begin{array}{l}\text { To determine the } \\
\text { relationship between } \\
\text { teachers' motivation and } \\
\text { use of instructional } \\
\text { resources in teaching } \\
\text { science and mathematics in } \\
\text { pre-primary schools }\end{array}$ & $\begin{array}{l}\text { Teachers' } \\
\text { Motivation }\end{array}$ & $\begin{array}{l}\text { Use Of Instructional } \\
\text { Resources In Teaching } \\
\text { Science And Mathematics } \\
\text { Across Pre-Primary School }\end{array}$ & $\begin{array}{ll}\text { Frequency } & \\
\text { counts } & \text { and } \\
\text { percentages } & \text { and } \\
\text { regression } & \\
\text { analysis } & \end{array}$ \\
\hline
\end{tabular}

The study also followed the principles of thematic analysis as proposed by Braun and Clarke, (2006). According to Braun and Clarke (2006) thematic analysis is a method for identifying and analyzing patterns (themes) contained by data. It simply organizes and describes data set in details. Furthermore, thematic analysis interprets various aspects of research. Thematic analysis was appropriate for this study because it is not grounded in any particular theoretical framework and can hence be applied across a broad range of qualitative approaches, making it flexible. In carrying out thematic analysis, the study followed suggested procedures to ensure rigor in data analysis which is grouped in six phases as presented in table 2.

Table 2: Qualitative Data Analysis Process

\begin{tabular}{|l|l|}
\hline $\begin{array}{l}\text { Phase } \\
\text { with data }\end{array}$ & Description of process \\
\hline $\begin{array}{l}\text { 2. Generalizing initial } \\
\text { codes }\end{array}$ & $\begin{array}{l}\text { Transcribing data by reading and re-reading the data, noting } \\
\text { down initial ideas. }\end{array}$ \\
\hline 3. Searching for themes & $\begin{array}{l}\text { Coding interesting features of the data in a systematic fashion } \\
\text { to each potential theme. }\end{array}$ \\
\hline 4. Reviewing themes & $\begin{array}{l}\text { Checking if themes work in relation to coded extracts and the } \\
\text { entire data set (level 2) generating a thematic map of the analysis. }\end{array}$ \\
\hline $\begin{array}{l}\text { 5. Defining and naming } \\
\text { themes }\end{array}$ & $\begin{array}{l}\text { On-going analysis to refine the specific of each theme, and } \\
\text { overall story the analysis tells, generating clear definitions and } \\
\text { names for each theme }\end{array}$ \\
\hline $\begin{array}{l}\text { 6. Producing the report } \\
\text { The final opportunity for analysis. Selection of vivid, extract } \\
\text { examples, final analysis of selected extracts, relating back the } \\
\text { analysis to the research question and literature, producing } \\
\text { scholarly report of the analysis }\end{array}$ \\
\hline
\end{tabular}


Source: Braun and Clarke (2006)

\section{DATA ANALYSIS RESULTS}

\subsection{Extend of Use of Instructional Resources in Teaching Science and Mathematics}

The first objective of this study sought to find out the extent to which teachers used instructional resources in teaching science and mathematics activities. Through observation, the researcher established the availability and adequacy of the instructional resources used in teaching of science and mathematics activities in pre-schools in the study area. The observation was made as either adequate, inadequate study first established the availability and adequacy of the instructional resources for teaching science and mathematics activities in pre-schools. This data was obtained from observation schedule.

Table 3: Extent of Use of Instructional Resources among Pre-school Teachers

\begin{tabular}{|c|c|c|c|c|c|c|c|c|}
\hline \multirow{3}{*}{$\begin{array}{l}\text { Instructional } \\
\text { Resources }\end{array}$} & \multicolumn{8}{|c|}{ Frequency of Use } \\
\hline & \multicolumn{2}{|c|}{ Always } & \multicolumn{2}{|c|}{ Sometimes } & \multicolumn{2}{|c|}{ Rarely } & \multicolumn{2}{|c|}{ Never } \\
\hline & Freq & $\%$ & Freq & $\%$ & Freq & $\%$ & Freq & $\%$ \\
\hline Real Objects & 4 & 8 & 11 & 22 & 24 & 48 & 11 & 22 \\
\hline Charts & 31 & 62 & 13 & 26 & 6 & 12 & 0 & 0 \\
\hline Flash Cards & 0 & 0 & 6 & 12 & 11 & 22 & 33 & 66 \\
\hline Pictures & 7 & 14 & 22 & 44 & 12 & 24 & 9 & 18 \\
\hline Play materials & 19 & 38 & 21 & 42 & 9 & 18 & 1 & 2 \\
\hline ICT resources & 2 & 4 & 5 & 10 & 14 & 28 & 29 & 58 \\
\hline Course books & 48 & 96 & 2 & 4 & 0 & 0 & 0 & 0 \\
\hline Syllabus & 50 & 100 & 0 & 0 & 0 & 0 & 0 & 0 \\
\hline Models & 4 & 8 & 7 & 14 & 33 & 66 & 6 & 12 \\
\hline Songs & 24 & 48 & 20 & 40 & 5 & 10 & 1 & 2 \\
\hline
\end{tabular}

The results show that the majority (48\%) of the pre-school teachers always used songs in instruction, $22 \%$ sometimes used real objects in teaching while only $8 \%$ of the teachers always used real objects as teaching resources. The study revealed charts, course books and syllabuses were the most used instructional resources among preschool teachers in Athi River sub-county. Charts were always used by $62 \%$ of the teachers, course books were used by $96 \%$ while syllabuses were used by all the teachers. Course books and the syllabuses were mostly used since the study established that they were core required books and professional documents that were necessary for effective teaching. The study revealed that $48 \%$ of the teachers always used songs as instructional resource while $40 \%$ used songs sometimes. The study however indicated that some key instructional resources were commonly not used by pre-school teachers in the study area. For 
instance, $66 \%$ of the teachers indicated that they rarely used models while $12 \%$ never used models in teaching. From the study findings, $22 \%$ of the teachers rarely used flash disks while $66 \%$ of the teachers never used flash disks in teaching. While in the $21^{\text {st }}$ century ICT resources have been shown to improve instruction and pupil achievement, more than half (58\%) of the pre-school teachers in the study area never used them for instruction. Audio tapes and videos are integral resources in teaching science and mathematics. Lack of use of ICT resources and other vital instructional resources among pre-school teachers in Athi River is a possible cause of poor performance in science and mathematics activities among pre-school pupils.

On the same context it has been stated that teacher's gender, academic qualifications and teaching experience doesn't influence the utilization of instructional resources in any level of teaching according to the study done by Ngeru (2015). on his study about influence of teacher characteristics on utilization of instructional resources in teaching number work in preschools in west lands Nairobi county. Koech (2017) found out that age of learners, entry behaviour, number of children, sex, social economic background of the learners, safety of the school environment and the abilities plus the language level of the learners greatly influences the selection of instructional resources. All the above factors will determine the extent of the teachers' use of instructional resources in teaching science and mathematics

On interviewing the teachers on the extend of use of instructional resources in teaching;

Teacher A stated that most times I teach using only the text book because have no time to look or money to pay other resources to use since our school cannot afford.

Teacher B echoed that I have been teaching mathematics and science for many years without using any other resources apart from the syllabus and my students have been passing very well, so whether you use instructional resources or not depends on many factors.

Instructional resources are not ends in themselves but means of attaining specific instructional functions. The ability of the teacher to effectively use the available instructional resources optimizes the attainments of instructional situation; this varies with the level of use, teacher competency and teachers 'levels of training. For instance, a situation where an electronics teacher pays "lip service" to activityoriented instructional methods and resources that could enhance

Creative thinking in the learners negates the objectives of electronics education for learners in preschools stated Teacher $C$ during the interview on the extent of use of instructional resources by teachers;

On support of the study Karaka and Fabian (2007) stated instructional resources are crucial to any successful teaching and learning process worldwide. This is because these resources aid the teacher to transfer the content to learners effectively, therefore teacher-use of instructional resources in teaching is paramount. It has been noted that when children are exposed to various instructional resources they tend to be active and involved in the learning process better. Therefore it is worth noting that pre -primary school teachers can testify that teaching become easier with the use of instructional resources, according to Mwonga\&Wanyama ,(2012). A study done by Mwong and Wanyama (2012), revealed that teaching and learning resources not only enhances a Child's acquisition of science skills but also ensures that the transition from preprimary to primary school is smooth. Therefore, all the education stakeholders should ensure that the teaching and learning resources are available in pre-primary school centress. Muilkiungu (2003), suggests that teachers 
should use variety of teaching learning resources easily found within the locality. It is the responsibility of the stakeholders to ensure that the required resources for learning are provided to enhance learning of children in ECDE centers. Muikiungu notes that the teacher is the main source of teaching learning resources is that he/she initiates their provision in the centers like, involving the children in the material collection. According to Muithungu (2003), teaching/ learning resources can be made available by parents and the community as a whole for the ECDE centers within the locality. This can be, successfully done by organizing for material making day in school. The community members and parents can collect and others can donate to the school. Meet and share, encouraging early enrolment and learn to provide learning resources.'

In addition to the above findings, $\mathrm{Ng}$ 'etich and Chemei (2015) noted that insufficient. And lack of available instructional materials in the sampled schools make teaching of conflict and resolutions in primary schools very difficult. Thus the availability of instructional resources makes teacher ready to use as they make teaching real, purposive and meaningful to the learners as they enjoy learning with resources which make their learning interesting and pleasurable. In support of the current study; Waithaka(2005) observed that in Kenya ECE curriculum developed by KICD has provision for learners to have adequate resources to interact with, but most learners in ECDE centers, however they do not interact with a variety of instructional resources in number work. This is because most preschool teachers do not care and most of the time, teach without adequate resources, hence learners fail to develop learning concepts in number work. She further observed that preschool teachers emphasized academics and gave little or no time for learners to interact freely with instructional resources. Joash (2011) in his research on survey of availability and utilization of learning materials in preschools found out that most of the preschool teachers were not utilizing relevant instructional resources and this affected children's performance. Hence support the current study finding which found that the extend of teachers' use of instructional resources affects the future outcomes of the learners achievements in schools.

\subsection{Teachers' Levels of Training and Use of Instructional Resources}

The second objective of this study sought to find out the how of teachers' levels of training affects the use of instructional resources in teaching science and mathematics among pre-primary school teachers. The results are illustrated in Table 4 below.

Table 4: Cross Tabulation of Pre-school Teachers' Levels of Training and Use of Instructional Resources

\begin{tabular}{|c|c|c|c|c|c|}
\hline \multirow[t]{2}{*}{ Use of Instructional Resources } & & \multicolumn{4}{|c|}{ Teachers levels of training } \\
\hline & & $\begin{array}{l}\text { None } \\
(n=8)\end{array}$ & $\begin{array}{r}\text { Certificate } \\
\text { ECDE } \\
(n=6)\end{array}$ & $\begin{array}{r}\begin{array}{r}\text { Diploma } \\
\text { in }\end{array} \\
\text { ECDE } \\
(\mathbf{n}=\mathbf{2 6}) \\
\end{array}$ & $\begin{array}{r}\begin{array}{r}\text { Degree } \\
\text { in } \\
\text { ECDE } \\
(n=10)\end{array} \\
\end{array}$ \\
\hline \multirow{2}{*}{$\begin{array}{l}\text { 1. I make use of the models in teaching } \\
\text { science and math }\end{array}$} & $\bar{F}$ & 4 & 3 & 17 & 8 \\
\hline & $\%$ & 50 & 50 & 65.4 & 80 \\
\hline \multirow{2}{*}{$\begin{array}{l}\text { 2. I make use of resource persons in } \\
\text { teaching science and math }\end{array}$} & $\bar{F}$ & 1 & 4 & 15 & 9 \\
\hline & $\%$ & 12.5 & 66.7 & 57.7 & 90 \\
\hline \multirow{2}{*}{$\begin{array}{l}\text { 3. I make use of excursions/field trips } \\
\text { in teaching science and math }\end{array}$} & $\bar{F}$ & $\overline{0}$ & 2 & 14 & 10 \\
\hline & $\%$ & 0 & 33.3 & 53.8 & 100 \\
\hline \multicolumn{2}{|c|}{$\mathrm{F}$} & 7 & \multicolumn{2}{|c|}{24} & 10 \\
\hline
\end{tabular}


International Journal of Current Aspects, Volume 3, Issue II, 2019, PP 159-185, ISSN 2616-6976 iJCAB

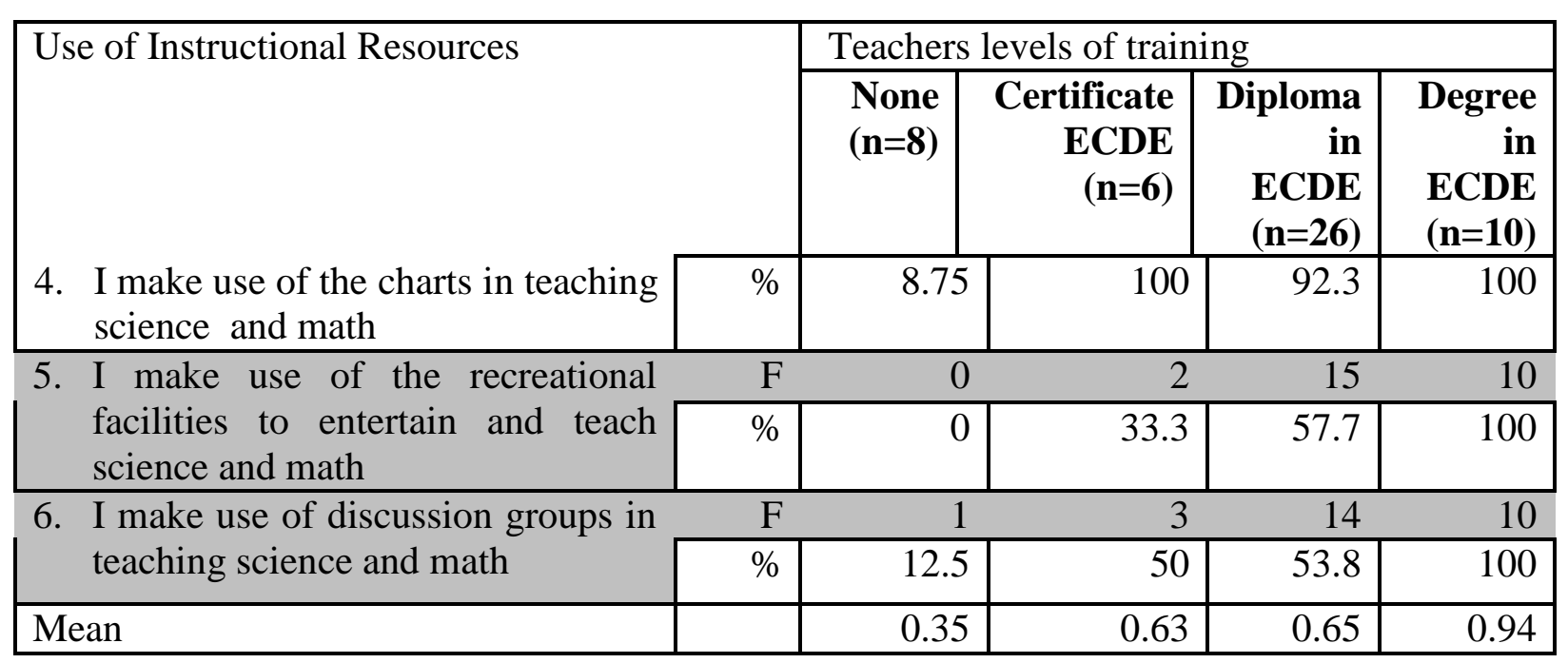

Table 4 above reveals that the extent of use of instructional resources was high among those teachers with bachelor's degree (mean $=0.94$ ) while the use of instructional resources in preschool was lowest in teachers with no training in ECDE (mean=0.35). For instance, while all teachers with Bachelors' degree used excursions/fieldwork trips, charts, recreational facilities and discussion groups in their teaching, none of the teachers with no training used any of them other than charts. This implied that teachers with higher qualifications understood the importance of the use of instructional resources in teaching mathematics and sciences among pupils in pre-schools than those without any training at all. On the other hand, teachers with less or no training, rarely used instructional resources because either they did not understand their importance and therefore they were not available or they did not know when and how to use them. It was noted that all teachers who participated in the study said that they made use of text books in the teaching of science and mathematics subjects. However, such important instructional activities in science as excursions/field trips in teaching science and mathematics recreational facilities were not fully used by pre-school teachers who had no training in ECDE.

These findings imply that they had limited skills and knowledge to incorporate different instructional resources in teaching and learning of science and mathematics in ECDE centers. The findings also meant that teachers who were more qualified academically and professionally were likely to influence pre-school children to highly achieve in science and mathematics activity than less qualified teachers. The conclusion is that there is a difference among pre-school teachers' levels of training and the extent at which they effectively select and use instructional resources in teaching Science and mathematics in ECDE centers. On the same vein, Nannyonjo's (2007) study of factors influencing learning achievement in Ugandan schools, found out that teachers' characteristics may contribute to the improvement of learners' performance; these characteristics include; teachers' training levels, in-service training of teachers, age, teachers' experience, tenure of leadership, teaching strategies and evaluation systems in a school. This finding concurs with that of Olembo, Wanga and Karangu (2002) on role of teachers in school performance in Nyanza Province, who also pointed out that, learners' performance depends on the role of the teacher in curriculum planning, classroom management, instructional programme and general curriculum implementation. Hence, the role of the teacher is significant in influencing learners' performance in examinations. 
According to UNESCO (2012), though the Kenyan government has made efforts to ensure "education for all" as previously suggested by the Millennium Development Goals as well as the UNESCO Medium Term Strategy (2008-2013), Kenya still however, faces serious shortage of qualified teachers which is causing schools performance to be negatively affected. The report also reiterated that the problems of shortage of financial and human resources, particularly physical infrastructures and teaching personnel are factors influencing children's education. Beecher (2009) also echoed these sentiments when he found that lack of trained teachers in schools contributes to the poor performance. It was for these reasons that the government of Kenya established an institution referred to as KESI, Kenya Education Staff Institute (KESI) to scale up professional and managerial training for the provision of quality education. Kangori (2014) also revealed that teachers with bachelors' degree were the best in implementing science and mathematics activities while those with no formal training in ECDE were the poorest. In his study, Kangori (2014) also revealed that a whole class of 14 children taught by an untrained teacher achieved very low and $76.7 \%$ of the low achievers were under care of teachers with certificate in ECDE. The study findings also concur with Jacob (2007) that full certification of teachers is positively related to student achievement in Science and mathematics. The subject area of teachers is one of the teacher qualification most consistently and strongly related to improved student success in academics. The findings also agree to those of Raymond (2001) who showed that teachers with higher licensure test scores have a marginal positive impact on middle school science and mathematics achievement. According to Kathuri (1986), a professionally trained teacher contributes more positively to effective learning than untrained one. This explains why teacher training exists as a major part of education systems throughout the world.

A study by Karuga (1996) revealed that only $80 \%$ of science and mathematics teachers in Kenya were qualified and the issue of teachers could be enhanced by advancing in education through inservice training. The findings are in line with Darling-Hammond (2001) who noted that sustained professional development that is aligned with the curriculum and focused on instruction positively effect on school level achievement in Science and mathematics at both Early childhood and high school studies. Therefore, higher quality early childhood education programs are those where teachers have bachelor's degrees specifically in majors of child development or similar areas according to Whitebook \& Ryan, (2011). During another interview with the head teachers, the respondents were asked to explain how teachers' qualification influenced the use of instructional resources in teaching science in pre-primary schools. One of the head teachers reported that:

"Training of teachers in ECDE is important in acquisition of basic skills in selecting suitable instructional resources for teaching specific concepts in Science and mathematics in pre-primary schools."

Another respondent added that:

"Teacher qualification is significant in preparation and updating of professional documents which ensure proper planning, set the pace and scope for work coverage and help in evaluation. It generally enables the teachers to prepare before presenting science and mathematics related activities to learners. Thus, the higher the qualification of the teacher the higher the performance among pupils in their tests because they effective use the instructional resources available"

In disagreement with the findings of the current study, Xu, Jane and Collin (2011) reported that there is no association between teachers holding master's degree and students' science and 
mathematics test score gains in any level or grade. Also in contrast to the study findings, Early (2006) found that teachers who had more than a Bachelor's degree received higher scores on the teaching and interaction subscales of the Early Childhood Environment Rating Scale (ECERS) than those teachers who had an associate's degree. Nevertheless, only a few studies have proved these claims which are mostly based at the school level.

During the interview with the head teachers, it was found that teachers' training levels and professional qualification have positive influence on the achievement of pre-school children in science and mathematics activities. One of the head teachers had this to say when interviewed;

Instructional resources are not ends in themselves but means of attaining specific instructional functions. The ability of the teacher to effectively use the available instructional resources optimizes the attainments of instructional situation; this varies with the level of use, teacher competency and teachers "levels of training. For instance, a situation where an electronics teacher pays "lip service" to activityoriented instructional methods and resources that could enhance creative thinking in the learners negates the objectives of electronics education for learners in preschools

This implies that the delivery of quality instruction in the classroom in any education system depends largely on academic qualification, quality and competence of the teachers. This is because the teachers are expected to perform the important function of guiding, directing, evaluating, imparting, asking and answering questions among others for maximum benefits of the learners. Similarly, Goe, (2007) in his study reiterated that teacher qualifications have greatly influence the use of instructional resources in teaching science and mathematics and mechanically promotes children 'achievements. Moreover, studies done by Rice, (2003); Zeichner\& Conklin, (2005) found that teacher trainings are related to children's achievements, as stated by came up with their uniform test scores to find on the connection between teacher qualifications and children's performance. Zeichner\& Conklin, (2005) also in their study on the effects of professional qualifications of financial accounting on academic performance, revealed that teachers with sound training were equipped with the requisite competence that enable them to produce effective service in teaching compared to less trained teachers. A survey by GOK and UNICEF (1995) revealed that lack of teachers training and poor teacher retention as key barriers to effective curriculum implementation. The key to getting teachers committed to an innovation is to enhance their knowledge of the program. This means teachers need to be trained and workshops organized for professional development.

\subsection{Teachers' Gender and the Use of Instructional Resources in Teaching Science and mathematics in Pre-Primary Schools}

The third objective of this study sought to find out the influence of teachers' gender on the use of instructional resources in teaching science and mathematics in pre-primary schools in AthiRiver sub county Kenya. The use of instructional resources was assessed through a Likert scale consisting of 12 items. The researcher then cross-tabulated pre-school teachers' gender and the use of instructional resources in teaching science and mathematics activities. The results have been presented and discussed using mean as shown in Table 4.6.

\section{CONCLUSIONS}

The study concluded that teacher training is a significant factor since it enables teachers acquires basic skills in implementing curriculum. Well trained teachers have the capability to select and use 
suitable instructional resources in teaching specific concepts in Science and mathematics. The study concludes that there is a positive relationship between the teacher qualification and teachers use of instructional resources in teaching and learning Science and mathematics activities.

\section{RECOMMENDATIONS}

Based on the study findings and conclusions the following recommendations that a pre-school teacher is recommended to have a roper academic background and be professionally trained and specialize on child development. This should be facilitated by the Ministry of Education through in-service training. Further, the Ministry of Education should ensure proper implementation of curriculum which needs effective use if instructional media in teaching. This would ensure production of pre-primary school teachers who have the ability to utilize instructional media in teaching regardless of their teaching experience. The school, parents, teachers and the education officers should warrant that the teaching and learning resources are available in pre-primary school centers for effective learning of science and mathematics to be realized.

The study found out there is need for further research in the following areas:

1. A similar should be replicated to a wider population of pre-schools Athi-River Sub-County and other parts of Machakos County to establish factors influencing implementation of Science and mathematics activity and compare the findings.

2. A similar study should be done in pure urban area to establish the dynamics of utilization of instructional resources in these ECDE centers which would establish a good platform for comparison with the findings of the current study.

3. Further research should be done to establish whether factors that had not been attained at the time of study like teacher participation of the parents and pupils' attitude towards Science and mathematics influence the use of instructional resources in teaching Science and mathematics among teachers in pre-schools.

\section{REFERENCES}

Ader, H., Van M., Deltaan, M., \&Beekman, A. (2008). Advising on research methods: A consultant's comparison. Netherlands: Johannes Van Kessel Publishers.

Afshari, M., Bakar, K. A., Luan, W. S., Samah, B. A., \& Fooi, F. S. (2009). Factors Affecting Teachers' Use of Information and Communication Technology. Online Submission, 2(1), 77-104.

Aiken, L. R. (1970). Attitude towards mathematics and science. Review of Educational Research p.558.

American Psychological Association (2009). Publication Manual of the American

Psychological Association, 6th edition. http://www.apastyle.org/manual.aspx.

An analysis of Nils's data. Paper presented at the American Education Research Association Annual Meeting. New Orleans.

Angus, M., Olney, H., \&Ainsley, J. (2007). In the balance: The future of Australia's primary schools. Canberra: Australian Primary Principals’ Association.

Antecol, H., Eren, O., \& Ozbeklik, S. (2012). The effect of teacher gender on student achievement in primary school: evidence from a randomized experiment.

Banilower, E. R., Smith, P. S., Weiss, I. R., Malzahn, K. A., Campbell, K. M., \& Weis, A. M. (2013). Report of the 2012 National Survey of Science and Mathematics Education. Horizon Research, Inc. 
Baylor, A.L. \& Ritchie, D. (2002). What factors facilitate teacher skill, teacher morale? and perceived student learning in technology using classrooms? Computer and Education, 39, 395-414.

Beggs, T. A. (2000). Influences and barriers to the adoption of instructional technology. Proceedings of the Mid-South Instructional technology.

Beggs, T.A. (2000). Influences and barriers to the adoption of instructional technology. Proceedings of the Mid-South Instructional Technology Conference. Murfreesboro,

Begi, N. (2007). A comparative study of preschool and lower primary school teachers, computer technology usage in teaching in Nairobi Province Kenya. VDM Verlag, Dr. Muller.

Bitengo, A. (2005).Factors that influence preschool Teacher's Attitude towards teaching of mathematics in Kasarani Division. Unpublished Masters of Education Thesis, University of Nairobi.

Brill, S., \& McCartney, A. (2008). Stopping the revolving door: Increasing teacher retention. Politics \& Policy, 36(5), 750-774.

Broadley, T., J. Downie and D. Gibson. (2015). "Evolving learning paradigms: Re-setting the baselines and collection methods of information and communication technology in education statistics post-2015". Montreal: UNESCO Institute for Statistics.

Bryman, A. (2006). Integrating Quantitative and Qualitative Research: How Is It Done? Qualitative Research, 6, 97-113. http://dx.doi.org/10.1177/1468794106058877

Calder, N.S.; Campbell, (2016). Using mathematical apps with reluctant learners. DEME 2016, 2, 50-69.

Canadian Association of University Teachers. (2007). CAUT Almanac of Post-Secondary Education in Canada 2007. Ottawa, ON: Canadian Association of University Teachers

Carr, J. (2012) Does math achievement h'APP'en when iPads and game-based learning are incorporated into fifth-grade mathematics instruction? J. Inf. Technol. Educ. 2012, 11, 269-286.

Catchan, R. (2013). Reflections: How STEM becomes STEAM. The STEAM Journal, 1(1), Art. 22.

Chaplin, T. M., \& Aldao, A. (2013). Gender differences in emotion expression in children: A meta-analytic review.

Charlesworth, R. (2015). Math and science for young children. Cengage Learning.

Chudgar, A. \& Sankar, V. (2008). The relationship between teacher gender and student achievement: Evidence from five Indian states. Compare: A Journal of Comparative and International Education, 38 (5), 627-642

Clements, D. H., \& Sarama, J. (2014). Learning and teaching early math: The learning trajectories approach. Routledge.

Colgrove, A. (2012). Approaches to Teaching Young Children Science Concepts and Vocabulary and Scientific Problem-solving Skills and Role of Classroom Environment. Comput. N. Z. Sch. Learn.Lead. Technol. 2010, 22, 1-16.

Czerniewicz, L., \& Brown, C. (2005). Access to ICTs for teaching and learning: From single artefact to inter-related resources. International Journal of Education and Development using ICT, 1(2). 
Darling-Hammond, L. (2000). The research and rhetoric on teacher certification: A response to 'Teacher certification considered'. New York: National commission on teaching and America's future.

Denscombe, M. (2010). The Good Research Guide for Small Scale Research Projects (4th ed.). Buckingham Open University Press.

Eble, E. K. (1988). The craft of teaching. A guide to mastering the profession Art (2 ${ }^{\text {nd }} \quad$ Ed.). San Francisco: The Jossey Bass publishers. Delhi: New Age International. Education. Retrieved from http://bit.ly/OD4Gsb

Eccles, J. S., \& Wigfield, A. (2002). Motivational beliefs, values, and goals. Annual Review of Psychology, 53, 109-132.

Eison, J. (2010). Using active learning instructional strategies to create excitement and enhance learning. Jurnal Pendidikantentang Strategi Pembelajaran Aktif (Active Learning) Books, 2(1), 1-10.

Erden, F. T. (2009). A course on gender equity in education: Does it affect gender role attitudes of preservice teachers? Teaching and teacher education, 25(3), 409-414.

European Commission. (2013). Survey of Schools: ICT in Education. Benchmarking Access, Use and Attitudes to Technology in Europe's Schools. Belgium: European Commission.

Gall mc \&Borg( 2003).Educational Research;An Introduction ( $7^{\text {th }}$.edition) Boston;Allyn\&Bacon.

Fullan, M. (2014). Leading in a culture of change personal action guide and workbook. John Wiley \& Sons.

Goe, L. (2007). The link between teacher quality and student outcomes: A research synthesis. Washington, DC: National Comprehensive Center for Teacher Quality. Retrieved from http://www.tqsource.org/link.php.

Harris, D. N., \& Sass, T. R. (2009). The effects of NBPTS-certified teachers on student achievement. Journal of policy analysis and management, 28(1), 55-80.

Hattie, J., \& Yates, G. C. (2013). Visible learning and the science of how we learn. Routledge.

Hattie, J., \& Yates, G. C. (2013). Visible learning and the science of how we learn. Routledge.

Hegedus, S. (2013) Young Children Investigating Advanced Mathematical Concepts with Haptic Technologies: Future Design Perspectives. Math. Educ. 2013, 10, 87-107.

Herzberg, F. (1968). The Motivation-Hygiene concept and problems of manpower.Retrieved13thFebruaryfromhttp//en.wikipedia.org.http://www.col.org/resources/u blications/Pages/detail.aspx?PID=421https://www.oercommons.org/about\#about-openeducational-resources.

Heyd-Metzuyanim .(2015)Vicious Cycles of Identifying and Mathematizing; A case study of the development of mathematical failure.journal of learning science 24( 4) 504-549.

Hiebert, J., \& Grouws, D. A. (2007). The effects of classroom mathematics teaching on students' learning. Second handbook of research on mathematics teaching and learning, 1, 371404.

Hoffmann, F., \& Oreopoulos, P. (2009). A professor like me the influence of instructor gender on college achievement. Journal of Human Resources, 44(2), 479-494.

Hoque, K. E., \& Zohora, M. F. (2014). Impact of teacher-gender on primary students' achievement: A study at Bangladesh standpoint. International Journal of Learning, Teaching and Educational Research, 3(1).

Infodev. (2015). "Teachers, Teaching and ICTs". Retrieved from http://www.infodev.org/articles/teachers-teaching-and-icts. 
Jacob, B.A (2007). 'Teacher,' the future of children and the challenges of staffingurban schools effectively 17(1): 129-153.

Jenkins, L. N., Floress, M. T., \& Reinke, W. (2015). Rates and types of teacher praise: A review and future directions. Psychology in the Schools, 52(5), 463-476.

Joash O. (2011) Survey of availability and utilization of learning materials in preschools of Suneka Zone Kisii South.Unpublished masters of education Thesis. University of Nairobi..

Jones, S. (2005). The Invisibility of the Underachieving Girl. International Journal of Inclusive Education, 9(3), 269-286.

Kathuri, N. S. (1986). Factors that influence pupils in KCPE. KU. Bureau of educational Research.

Koech F.(2017).Instructional Resources used in teaching and learning in pre schools in Kenya..IORS journal of humanities and social science(IOSR-JHSS)volume 22 isue 1 ve,3 janoury 2017.Retrived on may $, 16^{\text {th }}, 2017$.www.iosrjournals.org.

Kind, P., Jones, K., \& Barmby, P. (2007). Developing attitudes towards science measures. International Journal of Science, 29, 871-893.

Klassen, R. M., \& Chiu, M. M. (2010). Effects on teachers' self-efficacy and job satisfaction: Teacher gender, years of experience, and job stress. Journal of educational Psychology, 102(3), 741.

Kosgei, A., Mise, J. K., Odera, O., \& Ayugi, M. E. (2013). Influence of teacher characteristics on students' academic achievement among secondary schools. Journal of Education and Practice, 4(3), 76-82.

Kothari, R.C., (2004). Research Methodology: Methods and Techniques, $2^{\text {nd }}$ ed. Delhi: New Age International.

Kuecken, M., \& Valfort, M. A. (2012). The impact of student-teacher gender interactions on learning outcomes. Evidence from Sub-Saharan Africa. Mimeo.

Lampert, M., Beasley, H., Ghousseini, H., Kazemi, E., \& Franke, M. (2010). Using designed instructional activities to enable novices to manage ambitious mathematics teaching. In Instructional explanations in the disciplines (pp. 129-141). Springer US.

LINCOLN. Guba, E. G., \& Lincoln, Y. S. (1994). Competing paradigms in qualitative research. In N. K. Denzin \& Y. S. Lincoln (Eds.), Handbook of qualitative.

Loucks-Horsley, S., Stiles, K. E., Mundry, S., \& Hewson, P. W. (Eds.). (2009). Designing professional development for teachers of science and mathematics. Corwin Press.

Melhuish, K.; Falloon, G (2010). Looking to the future: M-learning with the iPad.

Meyer, B. (2015) iPads in inclusive classrooms: Ecologies of learning. In E-Learning Systems, Environments and Approaches Theory and Implementation; Isaias, P., Spector, J.M., Ifenthaler, D., Eds.; Springer: Dordrecht, The Netherlands, 2015.26. Gibson, J.J. The Ecological Approach.

Misigah,Kinyanjui \&Ohaga (2013);One Village One Product( OVOP)-Regional Sustainable Development in Kenya.http;journal.jkuat.ac.ke/index.php/article/view/1086.s

Mugenda and Mugenda (2009).Research Methods; Quantitative and Qualitative Approaches,NAIROBI;ACTS.

Mondal, N. K. (2011). Evaluation of English Language Teaching Methods Used in Higher Secondary Education in Bangladesh. Language in India, 11(12).

Morrison, F. J., Bachman, H. J., \& Connor, C. M. (2005). Current perspectives in psychology. Improving literacy in America: Guidelines from research.

Muithungu CE (2003): Teaching resources for young children. Longhorn Publishers Nairobi 
Mutekwe, E., Modiba, M., \& Maphosa, C. (2012). Female students' perceptions of gender and academic achievement: a case of sixth form girls in Zimbabwean school. Journal of Social Sciences, 32(1), 111-120.

Mbwesa j(.2006); Introductio to Management Research.Astudents'Handbook.Nairobo Jomo Kenyatta university Foundation.

Mwonga, S. C. J., \& Wanyama, M. N. (2012). Dealing with the prevailing attitudes and challenges for effective implementation of early childhood music and movement curriculum in Eldoret municipality, Kenya. Research Journal in Organizational Psychology and Educational Studies (RJOPES), 1(5), 295.

National Research Council. (2009). learning science in informal environments: People, places, and pursuits. National Academies Press.

Ndawula S., (2014). Teaching with Sponsored Instructional Materials: Attitudes of Teachers in Uganda, Journal of Educational Media \& Library Sciences 47:1

Ng'asike, J. T. (2012). Training of Science Teachers for Early Childhood and Primary Grades in Kenya. New Zealand Journal of Teachers' Work, 9(1).

Ngeru E, (2015).Influences of teacher characteristics on utilization of instructional resources in teaching number work in preschool in Nairobi. Master's thesis of Nairobi University.

Ngololo, E. N. (2012). Factors affecting ICT policy implementation in rural Namibian schools.

Odunaike, K. O., Ijaduola, K. O., \& Amoda, M. B. (2013). Empirical Analysis of Teachers' Gender and Secondary School Students' Academic Performance. Asian Economic and Financial Review, 3(3), 355.

Okobia, E. O. (2011). Availability and teachers' use of instructional materials and resources in the implementation of social studies in junior secondary schools in Edo State, Nigeria. Review of European studies, 3(2), 90.

Okobia, E.O. (2011). Availability and Teachers' Use of Instructional Materials and Resources in the Implementation of Social Studies in Junior, Secondary Schools in Edo State, Nigeria Review of European Studies Vol. 3, No. 2

Okoro, C. C., Ekanem, I. E., \& Udoh, N. A. (2012). Teacher gender and the academic performance of children in primary schools in Uyo Metropolis, Akwa Ibom State, Nigeria. Journal of Educational and social Research, 2(1), 267-273.

Okwelle, P. C. and Allagoa, F. O. N (2014). Enhancing Teachers' Competence in the Use of Instructional Materials in Electronics Education in Senior Secondary Schools in Nigeria, Research on Humanities and Social Sciences, Vol .4, No. 2

Oladejo, M. A., Olosunde, G. R., Ojebisi, A. O., \& Isola, O. M. (2011). Instructional materials and students' academic achievement in physics: some policy implications. European Journal of Humanities and Social Sciences, 2(1).

Onasanya, S. A. (2008). Preparing the primary school teachers on selection, Production and use of instructional media for effective classroom teaching. University of Ilorin, Nigeria.

Oso \& Onen (2010). Evolving activities and semiotic mediation in teacher-child interaction around simple objects. Educational and Child Psychology, 27(4), 22.

Rice, J. K. (2003). Teacher quality: Understanding the effectiveness of teacher attributes. Washington, DC: Economic Policy Institute.

Sapire, I. M. (2011). Investigating the take-up of Open Educational Resources for Maths Teacher Education: a case study in six Higher Education sites in South Africa (Doctoral dissertation). 
International Journal of Current Aspects, Volume 3, Issue II, 2019, PP 159-185, ISSN 2616-6976

iJ $\mathrm{I} C A B$

Sarama, J., \& Clements, D. H. (2009). Early childhood mathematics education research: Learning trajectories for young children. Routledge.

Shenton, A. K. (2004). Strategies for Ensuring Trustworthiness in Qualitative Research Projects. Education for Information, 22, 63-75.

Shonkoff, J. P., \& Phillips, D. A. (2013). Committee on Integrating the Science of Early Childhood Development; National Research Council and Institute of Medicine 2000. From neurons to neighborhoods: the science of early childhood development.

Sinclair, N.; Heyd-Metzuyanim, E (2014). Learning number with Touch Counts: The role of emotions and the body in mathematical communication. Technol. Knowl. Learn. 2014, 19, 81-99.

Summak, M. S., \& Samancioglu, M. (2011). Assessment of technology integration in vocational education and training schools. International Journal of Education and Development using Information and Communication Technology, 7(1), 68.

teachers' professional development". Journal of Computer Assisted Learning. DOI:10.1111/jcal.12031

Tsui, A. B. (2001). Classroom interaction. The Cambridge guide to teaching English to speakers of other languages, 120-125.

Twining, J et al. (2013). "Moving education into the digital age: The contribution of

Twining, P. and F. Henry (2014). "Enhancing 'ICT Teaching' in English Schools: Vital Lessons". World Journal of Education, Vol. 4, No. 2, 2014.

Twining, P., Davis, N., Charania, A., Chowfin, A., Henry, F., Nordin, H., \& Woodward, C. (2015). Developing new indicators to describe digital technology infrastructure in primary and secondary education.

Twining, P., N. Davis, A. Charania, A. Chowfin, F. Henry, H. Nordin and C.

UNESCO (2015a). Capacity Building on UNESCO's OER platform under the Kenya ICT Competency Framework for Teachers".

UNESCO (2015b). "What are Open Educational Resources (OERs)?”. Paris: UNESCO. Retrieved from http://www.unesco.org/new/en/communication-and-information/accessto-knowledge/open-educational-resources/what-are-open-educational-resources-oers/.

UNESCO (2015b). "What are Open Educational Resources (OERs)?". Paris: UNESCO. Retrieved from http://www.unesco.org/new/en/communication-and-information/accessto-knowledge/open-educational-resources/what-are-open-educational-resources-oers/.

UNESCO-UIS (2006). Teachers and Educational Quality: Monitoring Global Needs for 2015. Montreal: UNESCO Institute for Statistics.

UNESCO-UIS (2009). Guide to Measuring Information and Communication Technologies (ICT) in Education. Technical Paper No. 2. Montreal: UIS.

UNESCO-UIS (2009). Guide to Measuring Information and Communication Technologies (ICT) in Education. Technical Paper No. 2. Montreal: UIS.

UNESCO-UIS (2015). "Information and communication technology in education in sub-Saharan Africa: A comparative analysis of basic e-readiness in schools". Information paper No. 25. Montreal: UNESCO Institute for Statistics.

Van Aalderen-Smeets, S.I., Walma van der Molen, J.H., \& Asma, L.J.F. (in press). Primary teachers' attitudes towards science: A new theoretical framework. Science Education.

Wang, X., Wang, T. \& Ye, R. (2002). Usage of instructional materials in high schools: An analysis of Nils's data. Paper presented at the American Education Research Association Annual Meeting. New Orleans. 
Wang, X., Wang, T. \& Ye, R. (2002). Usage of instructional materials in high schools:

Wanjiku, C. (2014). Influence of teacher characteristics on motivation of preschool children in learning the English language in Starege District, Nairobi County. Unpublished Masters of Education. Thesis University of Nairobi.

Wanyonyi, K. M. and Makokha, R.N. (2015). The Utilization of Instructional Resources in Teaching Kiswahili Poetry in Secondary Schools in Kenya, International Journal of Academic Research in Business and Social Sciences, Vol. 5, No. 8

Westbury, I. (2000). Teaching as a reflective practice: What might Didaktik teach curriculum. Teaching as a reflective practice: The German Didaktik tradition, 15-39.

Whitebook, M. (2003). Early education quality: Higher teacher qualifications for better learning environments. A review of the literature. Berkeley: University of California www.col.org/resources/publications/Pages/detail.aspx?PID=421

Winters, M. A., Haight, R. C., Swaim, T. T., \& Pickering, K. A. (2013). The effect of samegender teacher assignment on student achievement in the elementary and secondary grades: Evidence from panel data. Economics of Education Review, 34, 69-75.

$\mathrm{Xu}, \mathrm{Z}$., Jane H., \& Colin, T. (2011). 'Making a difference? The effects of teaching for America in High School', Journal of policy Analysis and Management, 30(3): $\quad$ 447-469.

$\mathrm{Xu}$, Z., Jane H., \& Colin, T. (2011). 'Making a difference? The effects of teaching for America in High School', Journal of policy Analysis and Management, 30(3): 447-469.

Yates, S., \& Goodrum, D. (1990). How confident are primary school teachers in teaching science? Research in Science Education, 20, 300 - 305.

Yates, S., \& Goodrum, D. (1990). How confident are primary school teachers in teaching science? Research in Science Education, 20, 300 - 305.

Yeboah-Appiagyei, K. A. T. E., Joseph, O. T., \& Fentim, B. (2014). Effects of professional qualifications of financial accounting teachers on academic performance of financial accounting students in Tamale Metropolis of Ghana. International Journal, 4(8), 2307$227 \mathrm{X}$.

Zeichner, K. M., \& Conklin, H. G. (2005). Teacher education programs. In M. Cochran-Smith \& K. M. Zeichner (Eds.), Studying teacher education: The report of the AERA panel on research and teacher education (pp. 645-736). Mahwah, NJ: Lawrence Erlbaum Associates.

Zeichner, K. M., \& Conklin, H. G. (2005). Teacher education programs. In M. Cochran-Smith \& K. M. Zeichner (Eds.), Studying teacher education: The report of the AERA panel on research and teacher education (pp. 645-736). Mahwah, NJ: Lawrence Erlbaum Associates.

Zhang, D. (2008). The effect of teacher education level, teaching experience, and teaching behaviors on student science achievement. Utah State University.

This is an open-access article published and distributed under the terms and conditions of the $(\mathrm{cc}) \mathrm{EY}$ Creative Commons Attribution 4.0 International License of United States unless otherwise stated. Access, citation and distribution of this article is allowed with full recognition of the authors and the source.

Authors seeking to publish with an International Peer Reviewed Journal should consider www.ijcab.org by writing to the Editor at editor@ijcab.org. List of our Journals are Available at www.ijcab.org/journals 